\title{
MANAJEMEN KONTEN INSTAGRAM MILIK PEMERINTAH DALAM PROMOSI POTENSI PARIWISATA DAERAH DI KABUPATEN BANYUMAS PROVINSI JAWA TENGAH : STUDI TENTANG AKUN INSTAGRAM @DINPORABUDPAR_BANYUMAS
}

\author{
Shafira Anindyanari \\ Jurusan Ilmu Komunikasi \\ Fakultas Ilmu Sosial dan Ilmu Politik \\ Universitas Jenderal Soedirman \\ shanindyanr@gmail.com \\ Wisnu Widjanarko \\ Jurusan Ilmu Komunikasi \\ Fakultas Ilmu Sosial dan Ilmu Politik \\ Universitas Jenderal Soedirman \\ wisnuwidjanarko@unsoed.ac.id \\ Bambang Widodo \\ Jurusan Ilmu Komunikasi \\ Fakultas Ilmu Sosial dan Ilmu Politik \\ Universitas Jenderal Soedirman \\ bambang.widodo@unsoed.ac.id
}

\begin{abstract}
Tourism is one of the many resources owned by Banyumas Recency, a small town located in Central Java Province, which has potential impact in increasing the independence and welfare of the community. To promote Banyumas tourism, a communication medium that is in tune with the present and can built public motivation and interest in visiting the location is urgently needed. Instagram is a social media that responds as a digital communication platform that has the ability to build a reputation and sustainable reciprocal relationships with audiences/publics. This research aims to identify how to manage the Instagram account content@dinporabudpar_banyumas in supporting the tourism potential promotion system in Banyumas Regency. Using a qualitative approach and content analysis, the data were obtained through the upload documentation in Instagram from 21 September until 31 December 2019. The results showed that the uploaded content was categorized into three types, namely cultural, natural and culinary tourism. Uploaded content combines photo and video aspects with attention to informative-persuasive text narrative. This capability in management will have an impact on the development of regional development and become a form of public relations articulation for the government that takes sides in the implementation of development.
\end{abstract}

Keywords: social media, instagram, public relations, promotion, tourism 


\section{Pendahuluan}

Potensi daerah memiliki nilai strategis untuk dimanfaatkan dan dikembangkan dalam kerangka kemandirian dan kesejahteraan masyarakatnya. Marayasa, dkk (2018 : 85) mengungkapkan, untuk itu dibutuhkan kemampuan daerah untuk mengidentifikasi potensi yang diimiliki agar menjadi lebih optimal, terarah dan terancana sehingga mampu menjadi lokomotif pertumbuhan ekonomi daerah, sumber pendapatan daerah serta peningkatan pendapatan masyarakat. Salah satu faktor dalam upaya optimalisasi tersebut adalah kemampuan daerah dalam hal ini pemerintah - dalam berkomunikasi. Londa (2014: 3) mengungkapkan, wujud spesifik dari komunikasi tersebut adalah kemampuan kehumasan, di mana humas berperan sebagai komunikator pembangunan yang signifikan dalam mempengaruhi pembangunan di daerah. Hal ini dipertegas oleh Saroddin (2017 : 5) yang menjelaskan bahwa humas sesungguhnya berperan dalam menjembatani antara kepentingan pemerintah dan masyarakat daerah di satu pihak dengan pihak-pihak lain dalam meningkatkan kinerja pembangunan di masyarakat serta kegiatan pemerintahan. Tidak hanya sebagai jembatan komunikasi publik, Ruslizar (2014 : 4) juga melihat humas dalam fungsi mengelola informasi, dokumentasi dan publikasi di mana hal tersebut secara fungsi manajemen mendukung dalam rangka membangun citra dan membina kesalingmengertian hubungan antara lembaga dengan publiknya

Aspek potensi daerah yang membutuhkan peran kehumasan dalam upaya optimalisasinya adalah sektor pariwisata. Pariwisata sendiri bukan hanya tentang kawasan wisata di daerah, tetapi juga bias meningkatkan dan mengembangkan industri kreatifitas dan penyediaan jasa yang ada di daerah tersebut. Pengembangan potensi pariwisata pada gilirannya akan bermuara pada peningkatan kesejahteraan masyarakat, karena pariwisata mempunyai dampak pengganda yang besar terutama pada industri kreatif, yang memang mempunyai hubungan erat dengan pariwisata (Rismandkk, 2015: 31). Kabupaten Banyumas Provinsi Jawa Tengah merupakan daerah yang memiliki keanekaragaman wisata, baik alam, seni, kuliner, religi dan sejarah. Potensi pariwisata yang dimiliki oleh kabupaten ini relatif besar, yang ditandai dengan maraknya kunjungan masyarakat ke objek wisata.

Tabel 1. Jumlah Pengunjung Objek Wisata di Kabupaten Banyumas Tahun 2013-2018

\begin{tabular}{|c|c|c|c|c|c|c|}
\hline \multirow[t]{2}{*}{ ObjekWisata } & \multicolumn{6}{|c|}{$\begin{array}{c}\text { Jumlah Pengunjung Obyek Wisata di Kabupaten Banyumas } \\
\text { (Orang) }\end{array}$} \\
\hline & 2013 & 2014 & 2015 & 2016 & 2017 & 2018 \\
\hline CurugCipendok & 48.450 & 52.458 & 55.257 & 55.900 & 41.685 & 26.573 \\
\hline TelagaSunyi & 4.496 & 4.122 & 11.955 & 17.591 & 16.217 & 0 \\
\hline PancuranTiga & 53.507 & 39.897 & 67.561 & 75.409 & 73.045 & 20.540 \\
\hline PancuranTujuh & 20.714 & 18.380 & 28.878 & 34.173 & 25.337 & 0 \\
\hline $\begin{array}{l}\text { BumiPerkemahanB } \\
\text { aturraden }\end{array}$ & 1.709 & 7.550 & 1.801 & 0 & 0 & 0 \\
\hline
\end{tabular}




\begin{tabular}{lrrrrrr}
$\begin{array}{l}\text { LokawisataBaturra } \\
\text { den }\end{array}$ & 433.116 & 384.012 & 461.450 & 537.984 & 633.420 & 715.663 \\
Kalibacin & 6.002 & 6.456 & 6.036 & 6.870 & 7.319 & 9.286 \\
$\begin{array}{l}\text { WanawisataBaturra } \\
\text { den }\end{array}$ & 11.796 & 11.594 & 67.057 & 130.547 & 78.379 & 0 \\
CurugGede & 24.803 & 23.487 & 33.701 & 40.719 & 32.414 & 0 \\
CurugCeheng & 8.319 & 9.120 & 13.092 & 11.836 & 13.981 & 0 \\
\hline
\end{tabular}

Sumber: $\quad$ https://banyumaskab.bps.go.id/dynamictable/2019/11/22/49/banyaknyapengunjung-obyek-wisata-di-kabupaten-banyumas-2013-2018.html

Kemenarikkan potensi wisata yang ada tentunya membutuhkan upaya diseminatif-promotif yang terkelola dengan baik. Selain promosi yang bersifat konvensional, maka dengan perkembangan teknologi informasi dan komunikasi yang ada, maka media sosial menjadi salah satu instrumen yang dapat dimanfaatkan untuk mengoptimalkan promosi tersebut. Hal ini menjadi sebuah kualifikasi dan kompetensi yang dimiliki oleh kehumasan di pemerintah daerah untuk menyesuaikan diri dalam platform digital yang ada. Wright dan Hinson dalam Purworini (2014:4) mengungkapkan bahwa $85 \%$ praktisi kehumasan percaya jika media komunikasi baru telah mengubah bagaimana organisasi berkomunikasi, dengan lebih banyak porsi pada komunikasi eksternal dibandingkan internal. Meskipun kalangan instansi pemerintah sudah banyak yang menggunakannya, tetapi masih ada yang belum menggunakan. Oleh karena itu, faktor-faktor yang membuat media social belum diadaptasi di pemerintah kabupaten menjadi penting untuk dikaji agar dapat ditemukan solusi bagi penggunaan media sosial yang sesuai dengan karakteristik budaya organisasi pemerintah kabupaten (Purworini, 2014:4).

Salah satu media sosial yang banyak diminati adalah instagram. Brand Development Lead instagram APAC Paul Webster mengungkapkan, bahwa sejak diluncurkan pada tahun 2010 aplikasi instagram telah memiliki 400 juta lebih pengguna aktif dari seluruh dunia (Prihatiningsih, 2017:52). Instagram dianggap sebagai media sosial yang menarik karena media social ini fokus pada foto dan video durasi pendek, peningkatan citra dan hubungan timbal balik dibandingkan dengan media sosial lain yang berfokus pada kicauan. Survei pada 2017 menunjukkan bahwa instagram adalah platform media social terpopuler kedua, dengan 59\% pengguna online usia 18-29 tahun menggunakan instagram (Sakti \&Yulianto, 2018:2). Media social adalah media online yang mendukung interaksi sosial. Media social menggunakan teknologi berbasis web yang mengubah komunikasi menjadi dialog interaktif. Beberapa situs media sosial yang popular sekarang ini antara lain: blog, twitter, facebook, instagram dan wikipedia.

Berdasarkan uraian di atas, peneliti tertarik untuk meneliti bagaimana konten di media social khususnya instagram yang digunakan oleh Pemerintah Kabupaten Banyumas yang dalam hal ini adalah Dinporabudpar dalam mempromosikan potensi pariwisata daerah yang ada di Banyumas. Akun 
@dinporabudpar_banyumas dipilih sebagai objek penelitian karena akun tersebut merupakan akun instagram resmi milik Dinas Pemuda, Olah Raga, Kebudayaan dan Pariwisata Kabupaten Banyumas. Akun@dinporabudpar_banyumas memiliki jumlah pengikut yang cukup banyak, yaitu sebanyak 5.727 pengikut (per 15 April 2020). Selain itu, akun @dinporabudpar_banyumas memiliki konten yang bervariasi sehingga menarik untuk diteliti.

\section{Metodologi penelitian}

Riset ini menggunakan paradigma konstruktivisime dengan menggunakan metode analisis isi kualititatif dengan subjek penelitian konten pada akun media sosial instagram @dinporabudpar_banyumas yang dikelola oleh Dinas Pemuda, Olahraga, Kebudayaan dan Pariwisata Kabupaten Banyumas.

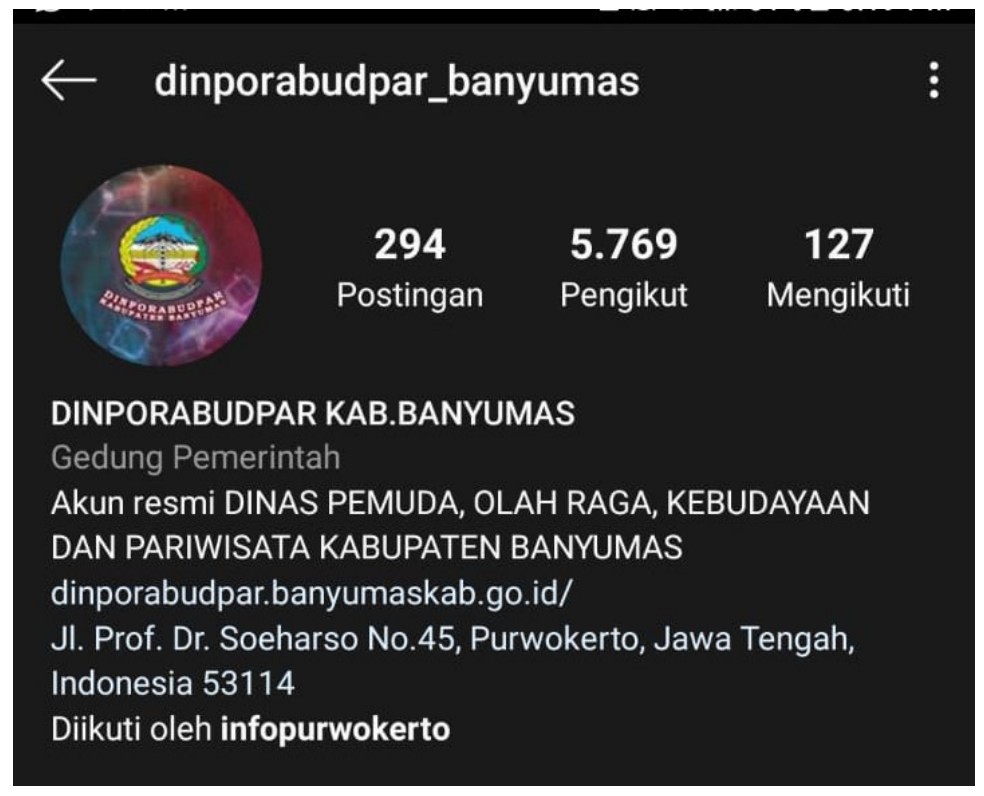

Gambar 1 Profil Instagram akun @dinporabudpar_banyumas

Data dikumpulkan dengan menggunakan studi dokumentasi, yakni mengumpulkan data-data atau mendokumentasikan postingan foto dan caption yang telah diunggah pada akun @dinporabudpar_banyumas periode 2 September 2019 - akhir Desember 2019, yaitu sebanyak 30 postingan. Selain itu, dilakukan juga observasi atau pengamatan terhadap konten-konten yang diunggah pada akun instagram@dinporabudpar_banyumas serta studi kepustakaan pendukung. Ada pun, analisis yang dilakukan untuk penelitian ini adalah dengan menggunakan metode analisis isi dan validitas atau keabsahan data dengan melakukan uji kredibilitas, transferabilitas, dependabilitas dan objektivitas.

\section{Tinjauan pustaka}

\section{Analisis Isi}

Analisis isi berhubungan dengan komunikasi atauisi komunikasi.Logika dasar dalam komunikasi, bahwa setiap komunikasi selalu berisi pesan dalam 
sinyal komunikasinya itu, baik berupa verbal maupun nonverbal. Sejauh ini, makna komunikasi menjadi amat dominan dalam setiap peristiwa komunikasi (Lestari, 2019: 5). Menurut Holsti dalam Vonna (2018: 33), analisis isi mengidentifikasi berbagai karakteristik dari isi pesan. Digunakan untuk menjawab pertanyaan "what" mengenai apa isi dari suatu pesan, "to whom" menguji hipotesis mengenai isi pesan yang ditujukan untuk khalayak yang berbeda, dan "how" berkaitan dengan penggunaan analisis isi untuk menggambarkan bentuk dan teknik-teknik pesan. Ada pun Eriyanto (2011 : 32-42) mengungkapkan, bahwa terdapat sejumlah tujuan analisis isi, yaitu menggambarkan karakteristik dari pesan, menggambarkan secara detail isi, melihat pesan pada khalayak yang berbeda, melihat pesan dari komunikator yang berbeda dan menarik kesimpulan penyebab dari suatu pesan.

Dalam model analisis kualitatif, merujuk Bungin (2008 : 203) terdapat hal yang perlu diperhatikan, yakni Context, Process \& Emergence. Memahami situasi sosial di seputar dokumen atau teks yang diteliti akan dapat memahami kealamiahan dan makna budaya dari teks yang diteliti. Tidak hanya itu, menjadi penting pula untuk memahami bagaimana suatu proses produksi media atau isi pesannya dikreasi secara aktual dan diorganisasikan secara bersama di mana perlu menjadi pertimbangan penting tentang bagaimana pesan diproses, termasuk format pesan yang dianalisis sesuai keberadaannya dan bagaimana realitas dari objektif diedit kedalam realitas media tersebut. Serta yang tidak kalah pentingnya adalah pembentukan secara gradual/bertahap dari makna sebuah pesan melalui pemahaman dan interpretasi dari dokumen yang diteliti. Pembentukan tersebut akan memahamkan periset dalam memahami proses dari kehidupan sosial di mana pesan tadi diproduksi, sehingga mengetahui apa dan bagaimana si pembuat pesan dipengaruhi oleh lingkungan sosialnya, atau oleh bagaimana si pembuat pesan mendefinisikan sebuah situasi.

\section{Humas Pemerintah}

Humas pemerintah mempunyai peran yang sangat besar dalam system penyelenggaraan pemerintahan. Ada dua peran yang dimainkan oleh humas pemerintah yaitu : (1) peran taktis (jangka pendek) dan (2) peran strategis (jangka panjang). Dalam peran taktis (jangka pendek), Humas pemerintah berupaya memberikan pesan-pesan dan informasi yang efektif dapat memotivasi rakyat dan mempunyai pengaruh yang sangat besar terhadap rakyat melalui pesan-pesan yang disampaikan. Dalam pesan jangka panjang (peran strategis), humas pemerintah berperan aktif dalam proses pengambilan keputusan, dalam memberikan proses sumbang saran, gagasan dan ide yang kreatifsecaracemerlanguntukmelaksanakan program lembaga yang bersangkutan (Nurjanah, 2016: 132). Hal ini sejalan dengan pemikiran Nilasari (2012: 7) di mana secara garis besar tujuan humas pemerintah menyangkut tiga hal yaitu reputasi atau citra, jembatan komunikasi dan membangun hubungan yang saling memberi manfaat. Menurut Charles J. Fombrum (dalam Muflih\& Dany, 2018: 207), ada empat sisi reputasi dalam perspektif humas pemerintah, yaitu (1). Kredibilitas (Credibility). Kredibilitas ini mempunyai tiga karakteristik yaitu, memperlihatkan profitabilitas, dapat mempertahankan stabilitas dan adanya prospek pertumbuhan yang baik; (2) Terpercaya (Trusworthiness). Citra ini di mata karyawan, dimana organisasi 
mendapat kepercayaan dari karyawan, organisasi dapat memberdayakan karyawan dengan optimal dan organisasi dapat menimbulkan rasa memiliki dan kebanggaan bagi karyawan; (3) Keteran dalan (Reliability). Citra ini dibangun untuk publik, dengan selalu menjaga mutu produk atau jasa, menjamin terlaksananya pelayanan prima yang diterima publik; (4) Tanggung Jawab (Responsibility). Citra untuk masyarakat sekitar, seberapa banyak atau berarti organisasi membantu pengembangan masyarakat sekitar, seberapa peduli organisasi terhadap masyarakat.

\section{Hasil dan pembahasan Hasil}

Akun Instagram@dinporabudpar_banyumas adalah sebuah akun resmi milik Dinas Pemuda, Olahraga, Kebudayaan dan Pariwisata Kabupaten Banyumas, di mana kali pertama mengunggah adalah 21 November 2016. Akun @dinporabudpar_banyumas memiliki jumlah pengikut sebanyak 5.831 (per 24 Juli 2020) dan jumlah akun yang diikuti sebanyak 128 (per 24 Juli 2020). Bio akun ini yaitu "Akun resmi DINAS PEMUDA, OLAH RAGA, KEBUDAYAAN DAN PARIWISATA KABUPATEN BANYUMAS", dengan tautan dinporabudpar.banyumaskab.go.id yang merupakan website resmi Dinporabudpar Banyumas. Selain itu, akun ini juga mencantumkan alamat jelas kantor Dinporabudpar Banyumas yang berlokasi di Jl. Prof. Dr.Soeharso No.45, Purwokerto, Jawa Tengah, Indonesia 53114. Foto profil yang digunakan oleh akun@dinporabudpar_banyumas adalah logo Pemerintah Kabupaten Banyumas dengan tambahan latar belakang kombinasi warna biru tua dan ungu. Ada pun akun ini dikelola oleh seksi promosi dan pemasaran pariwisata yang berada di bidang pariwisata.

Terdapat 8 postingan terpilih dimana tiap konten dalam bentuk foto maupun video akan diidentifikasi berdasar simbol/ lambang yang terdapat di dalamnya, sedangkan untuk caption dianalisis karakteristik isinya berdasarkan penggunaan bahasa dan bentuk pesannya. Ada pun kedelapan konten spesifik tersebut adalah : 1) Festival Rewanda Bojana 2019, 2) Banyumas Wera 2019, 3) Grebeg Suran Festival 2019, 4) Batik Banyumas, 5) Bakmi Goreng Banyumas, 6) Taman Bale Kemambangan, 7) Bunga Tabebuya, 8) Safari Offroad Baturraden. Berdasarkan data tersebut, maka terklasifikasi dua jenis kategori konten unggahan, yakni wisata budaya dan wisata alam.Unggahan tentang Festival Rewanda Bojana 2019, Banyumas Wera 2019, Grebeg Suran Festival, Batik Banyumas dan Bakmi Gareng Banyumas masuk kategori wisata budaya. Ada pun unggahan tentang Taman Bale Kemambang, Bunga Tabebuya dan Safari Offroad dikategorikan sebagai wisata alam.

a. Konten Unggahan Wisata Budaya

1. Rewanda Bojana

Festival Rewanda Bojana adalah tradisi masyarakat Desa Cikakak Kabupaten Banyumas yang memberikan makan dengan berbagai buah dan sayuran kepada kera yang banyak hidup dan tinggal di sekitar Masjid Saka Tunggal. Event tahunan ini diselenggarakan oleh Dinas Olarahraga, Budaya dan Pariwisata (Dinporabudpar) Kabupaten Banyumas, dengan tujuan menggerakkan 
potensi wisata religi dan budaya, serta pakan kera disekitar Desa Cikakak. Peneliti menemukan tujuh postingan mengenai acara Festival Rewanda Bojana 2019 dalam akun instagram@dinporabudpar_banyumas. Tujuh postingan tersebut terbagi menjadi tiga postinganfoto dan empatpostingan video yang diunggah sebelum dan sesudah acara Festival Rewanda Bojana 2019 diselenggarakan.

Berdasar pada analisis, teridentifikasi beberapa simbol/ lambing dalam postingan mengenai Festival Rewanda Bojana 2019 di akun instagram @Dinporabudpar_banyumas. Tradisi yang dikemas menjadi event budaya ini berhasil mendatangkan ribuan orang dari seluruh desa di Kecamatan Wangon dan wisatawan tumpah ruah ikut dan menyaksikan prosesi tradisi Rewanda Bojana. Event yang diselenggarakan oleh Dinas Olahraga, Budaya dan Pariwisata (Dinporabudpar) Kabupaten Banyumas bertujuan untuk menggerak kan potensi wisata religi dan budaya, sekaligus menjaga lingkungan serta habitat para kera (Jateng.tribunnews.com, 2019).

Penggunaan bahasa pada caption postingan mengenai Rewanda Bojana 2019 yang diunggah pada 14 Oktober 2019 dan 17 Oktober 2019 menggunakan bahasa formal, karena pemakaian bahasanya sesuai dengan Ejaan yang Disempurnakan (EYD) yang berlaku Bentuk pesannya bersifat informatif. Informasi yang diberikan pada caption postingan yaitu mengenai pelaksanaan acara Festival Rewanda Bojana yang disertai keterangan waktu dan tempat. Penggunaan bahasa pada caption postingan mengenai Rewanda Bojana 2019 yang diunggah pada 15 Oktober 2019 dan 19 Oktober 2019 menggunakan bahasa informal.

\section{Banyumas Wera}

Banyumas Wera adalah agenda wisata berupa karnaval jalanan di Kabupaten Banyumas. Karnaval ini adalah kegiatan yang sebelumnya bernama Banyumas Extravaganza dan sekarang mulai tahun 2019 sudah berubah nama menjadi Banyumas Wera. Acara Banyumas Wera merupakan event tahunan yang diselenggarakan oleh Dinas Olarahraga, Budaya dan Pariwisata (Dinporabudpar) Kabupaten Banyumas. Dilansir dari fin.co.id, melalui acara BanyumasWera 2019, pemerintah Kabupaten Banyumas berharap pemerintah bias memberikan informasi terkait pariwisata dan Budaya Banyumas serta member apresiasi terhadap pelaku seni dan pelaku usaha batik. Kegiatan berbentuk karnaval jalanan tersebut digelar di Purwokerto, Kabupaten Banyumas, dengan mengambil rute dari depan Bioskop Rajawali, Jl. S. Parman, Jl. Jenderal Soedirman, dan berakhir di Alun-Alun Purwokerto (Solopos.com, 2019). Kostum, ebeg dan reog merupakan informasi tentang apa yang ada dalam acara Banyumas Wera 2019.

Penggunaan bahasa pada caption postingan mengenai Banyumas Wera 2019 yang diunggah pada 4 Desember 2019 menggunakan bahasa informal, dapat dilihat dari penggunaan frasa "don't miss it" yang merupakan kalimat berbahasa Inggris. Bentuk pesannya bersifat informatif. Informasi yang disampaikan yaitu hadirnya kembali acara Banyumas Wera di tahun 2019. Ada pun Penggunaan bahasa yang diunggah pada 9 dan 11 Desember 2019 menggunakan bahasa informal, dapat dilihat dari penggunaan frasa "more information" yang merupakan kalimat berbahasa Inggris. Bentuk pesannya bersifat informatif. Informasi yang disampaikan yaitu hadirnya Banyumas Wera di bulan Desember yang disponsori oleh Good Day. Namun, pada caption postingan mengenai 
Banyumas Wera 2019 yang diunggah pada 17 Desember 2019 menggunakan bahasa formal, karena pemakaian bahasanya sesuai dengan Ejaan yang Disempurnakan (EYD) yang berlaku. Informasi yang disampaikan yaitu mengenai arti dari kata "Wera" serta penjelasan tema yang diusung pada Banyumas Wera 2019. Informasi ini disampaikan karena pada tahun-tahun sebelumnya nama event tahunan ini lebih dikenal sebagai Banyumas Extravaganza. Terkait dengan perubahan nama kegiatan, hal itu berkaitan dengan adanya anggapan bahwa parade budaya tersebut mengekor festival yang digelar di daerah lain, keinggrisinggrisan, dan sebagainya.

\section{Grebeg Suran}

Grebeg Suran adalah upacara tradisional sedekah bumi yang dilaksanakan pada bulan Sura untuk tujuan tolak bala dengan cara bermacam-macam seperti ruwat bumi dan upacara selamatan di makam leluhur. Grebeg Suran dilaksanakan di Objek Wisata Baturraden oleh masyarakat Desa Karang mangu beserta Desa penyangga wisata Baturraden, upacara tersebut diselenggarakan setiap tahun dimulai pada malam 1 sura (Dianawati, 2011:1). Dalam tradisi rutin tahunan tersebut, diperebutkan empat gunungan. Dimana dua gunungan berasal dari pemerintah, sedangkan dua lainnya dari sumbangan masyarakat sekitar. Sebelum diperebutkan, gunungan diarak dari Wanawisata Baturraden menuju ke area parkir Bukit Bintang Baturraden. Dikutip dari radar banyumas.com, Pegiat Paguyuban Masyarakat Pariwisata Baturraden (PMPB), Supriyono menyebutkan, dari tradisi masyarakat, gunungan yang diarak terdiri dari pala kependhem (umbi-umbian), pala kesimpar yaitu sayur dan buah yang tumbuh di atastanah dan pala gumantung yaitu jenis buah dan sayur yang menggantung di pohonnya. Gunungan merupakan wujud syukur dari pelaku wisata dan masyarakat dari desa penyangga Baturraden atas hasil panen yang melimpah.

Berdasar pada analisis, peneliti telah mengidentifikasi lambang/symbol dalam postingan video yang diunggah oleh akun@dinporabudpar_banyumas mengenai Grebeg Suran Festival Baturraden 2019. Simbol/ lambing tersebut diantaranya pakaian adat Banyumas, gunungan, kambing kandhit, larungan dan tumpeng triwarna. Semua simbol/lambing tersebut merupakan komponen dan prosesi yang terdapat dalam acara Grebeg Suran Festival Baturraden 2019. Penggunaan bahasa pada caption postingan mengenai Grebeg Suran Festival Baturraden 2019, bahasanya menggunakan bahasa formal karena pemakaian bahasanya sesuai dengan Ejaan yang Disempurnakan (EYD) yang berlaku. Bentuk pesannya bersifat informatif. Informasi yang disampaikan yaitu video yang diunggah adalah serangkaian kegiatan dari acara Grebeg Suran.

\section{Batik Banyumasan}

Batik Banyumasan merupakan salah satu warisan budaya Indonesia yang berasal dari Banyumas, Jawa Tengah. Batik Banyumasan memiliki karakter motif tersendiri yang membedakan dengan motif-motif batik dari daerah lainya, yaitu salah satu cirinya adalah batik pedalaman yang banyak terinspirasi motif tumbuhan dan juga hewan. Sesuai dengan lingkungan di daerah Banyumas yang didominasi oleh hutan dan gunung. Selain itu, dalam proses pewarnaannya, batik Banyumas cenderung menggunakan warna tua atau gelap dengan karakter gambar yang tegas dan lugas (Audina, 2018:2). 
Berdasar pada analisis, peneliti telah mengidentifikasi lambang/symbol dalam postingan video yang diunggah oleh akun@dinporabudpar_banyumas mengenai Batik Banyumasan, simbol/lambing tersebut diantaranya canting, kain mori, lilin malam, cetakan cap. Simbol-simbol tersebut merupakan symbol dari proses pembuatan batik Banyumasan yang dibuat secara manual dan tradisional. Batik dibuat di atas bahan dengan warna putih yang terbuat dari kapas yang dinamakan kain mori. Motif batik dibentuk dengan cairan lilin dengan menggunakan alat yang dinamakan canting untuk motif halus, atau kuasuntuk motif berukuran besar, sehingga cairan lilin meresap kedalam serat kain. Kain yang telah dilukis dengan lilin kemudian dicelup dengan warna yang diinginkan, biasanya dimulai dari warna-warna muda. Pencelupan kemudian dilakukan untuk motif lain dengan warna lebih tua atau gelap. Setelah beberapa kali proses pewarnaan, kain yang telah dibatik dicelupkan kedalam bahan kimia untuk melarutkan lilin (Prasetyo \& Singgih, 2016: 53). Penggunaan bahasa pada caption postingan mengenai Batik Banyumasan menggunakan bahasa formal, karena pemakaian bahasanya sesuai dengan Ejaan yang Disempurnakan (EYD) yang berlaku Bentuk pesannya bersifat informatif. Informasi yang disampaikan yaitu pada tanggal 2 Oktober diperingati sebagai Hari Batik Nasional.

b. UnggahanKontenWisata Alam

1. Taman Bale Kemambang

Taman Bale Kemambang Purwokerto merupakan salah satu tempat wisata alam buatan sekaligus sebagai Ruang Terbuka Hijau (RTH). Bale dan kemambang merupakan kata asli dari Banyumas. Kata bale, berarti sebuah tempat yang biasa digunakan untuk sara sehan atau duduk-duduk santai atau sekadar berbincang-bincang. Sementara Kemambang, memiliki arti mengapung dalam bahasa Indonesia, jadi Bale Kemambang bias diartikan sebagai tempat bersantai yang mengapung (Banyumasku.com, 2018). Taman Bale Kemambang diresmikan oleh Bupati Banyumas Mardjoko pada tanggal 24 Februari 2014. Dengan tujuan menata kota dan ikut serta dalam program pemerintah Indonesia untuk melindungi, melestarikan, dan melakukan penghijauan di pusat-pusatkota (Banyumasku.com, 2018).

Berdasar pada analisis, peneliti telah mengidentifikasi simbol/ lambang pada postingan video yang diunggah oleh akun@dinporabudpar_banyumas mengenai Taman Bale Kemambang. Simbol/ lambing tersebut di antaranya Taman Bale Kemambang, musholla, dan air mancur. Ketiga simbol/ lambing tersebut merupakan informasi yang menggambarkan objek dan fasilitas yang ada di Taman Bale Kemambang. Taman Bale Kemambang seperti taman kota pada umumnya namun memiliki fungsi sebagai tempat rekreasi, bermain, dan bersantai (uhb.ac.id, 2018). Di tempat wisata ini, terdapat beberapa bagian yaitu area bermain anak, tempat duduk, ayunan, dan juga tempat untuk sholat yang disediakan di Taman Bale Kemambang. Penggunaan bahasa pada caption postingan menggunakan bahasa formal. Bentuk pesannya bersifat informatif yang menjelaskan bahwa video yang diunggah tersebut diambil di Taman Bale Kemambang Purwokerto.

2. Bunga Tabebuya

Pada pertengahan Oktober 2019 lalu, bunga Tabebuya bermekaran di berbagai kota di Jawa. Di Purwokerto, tanaman ini menjadi sorotan karena merupakan tanaman peneduh dan hias yang mengalami bloom atau (mekar 
serentak) di sepanjang Jalan Jenderal Sudirman. Tabebuya adalah jenis tanaman yang yang termasuk Suku Bignoniaceae berasal dari Brasil, Amerika Selatan. Tanaman ini dapat menjadi pohon yang besar bila dibiarkan tumbuh puluhan tahun (Liputan6.com, 2019). Dilansir dari tagar.id, tanaman tabebuya adalah bagian dari upaya pemerintah setempat menciptakan apa yang popular disebut green environtment atau pembangunan dengan pendekatan ramah lingkungan. Penghijauan dengan menanam banyak tabebuya dimaksudkan untuk mencipatakan kembali kesejukan dan juga keindahan.

Berdasar pada analisis, peneliti telah mengidentifikasi simbol/ lambing dalam postingan video yang diunggah oleh akun@dinporabudpar_banyumas mengenai bunga Tabebuya, simbol/ lambing tersebut yaitu Kota Purwokerto dan Bunga Tabebuya. Kedua simbol/ lambing tersebut menjelaskan bahwa Bunga Tabebuya tumbuh dan mekar di Kota Purwokerto dan punya daya tarik tersendiri hingga menjadi sorotan. Dosen Fakultas Biologi Unsoed Pudji Widodo mengatakan, jika sedang mekar, Tabebuya memang terlihat indah, hal itu jelas menambah keindahan kota, dan bias dikembangkan lagi di jalan-jalan yang lain (banyumasekspres.id.com, 2019). Bunga tabebuya itu lantas menjadi ajang swafoto masyarakat. Mereka mengunggah foto tersebut di media sosial dan viral (gatra.com, 2019). Penggunaan bahasa pada caption postingan mengenai Bunga Tabebuya menggunakan bahasa formal, karena pemakaian bahasanya sesuai dengan Ejaan yang Disempurnakan (EYD) yang berlaku. Bentuk pesannya bersifat informatif, yaitu menginformasikan bahwa pada saat itu bunga Tabebuya tengah bermekaran di Purwokerto.

\section{Safari Offroad Baturaden}

Wisata Safari Offroad Baturraden merupakan wisata yang berada di kawasan hutan wisata Baturraden, Kabupaten Banyumas, Jawa Tengah. Aktivitas minat khusus ini mengandalkan petualangan adrenalin di tengah hutan. Dilansir dari gatra.com, paketwisata Safari Offroad Adventure Baturraden ini memiliki jalur yang berbeda dengan daerah lain seperti Bromo ataupun Merapi. Wisatawan akan diajak berpetualangan membelah hutan pinus yang masih alami menaiki kendaraan dengan penggerak empat roda. Paket wisata ini hasil kerjasama dengan pelaku wisata, Kegiatan offroad menjadi simbol/ lambing dari wisata yang ditawarkan. Jalur offroad Baturraden ini digadang-gadang menjadi wisata adrenalin andalan di wilayah Banyumas.Jalur yang disiapkan meliputi Wana wisata Baturraden - Bukit Pandang - BPPTU Baturraden dan berakhir di Hutan Pinus Limpakuwus, Kecamatan Sumbang. Sementara untuk fun offroad dengan jalur sepanjang 10 kilometer berakhir di Desa Serang, Kecamatan Karangreja, Purbalingga. Penggunaan bahasa pada caption postingan mengenai Wisata Safari Offroad Baturraden menggunakan bahasa formal, karena pemakaian bahasanya sesuai dengan Ejaan yang Disempurnakan (EYD) yang berlaku. Bentuk pesannya bersifat informatif. Informasi yang disampaikan yaitu di Banyumas ada tempat wisata baru untuk yang suka bertualang.

c. UnggahanWisata Kuliner

Wisata kuliner menjadi suatu alternative dalam mendukung potensi wisata alam, wisata budaya, wisata sejarah dan wisata bahari. Wisata kuliner ini menjadi bagian dari jenis wisata yang ada, karena tidaklah lengkap kalau wisatawan yang dating tidak mencoba kuliner khas di daerah tersebut. Meskipun wisata kuliner 
sering dianggap sebagai produk wisata pelengkap, tetapi wisata kuliner potensial untuk dikembangkan karena wisatawan yang dating biasanya tertarik untuk mencoba makanan khas daerah tersebut (Besra, 2012:77). Berdasar pada analisis, peneliti telah mengidentifikasi simbol/ lambing dalam postingan video yang diunggah oleh akun instagram @dinporabudpar_banyumas mengenai Bakmi Gareng Banyumas, simbol/ lambing tersebut diantaranya bakmi, Desa Sudagaran RT 03/03 No.686 Kecamatan Banyumas, Banyumas, tungku pemasak dan kipas bambu. Bakmi merupakan simbol/ lambing dari produk kuliner yang ditawarkan. Dalam satu porsi bakmi, terdapat suwiran ayam, sawi, wortel dan telor. Bakmi ini disajikan dengan acar mentimun. Bakmi Gareng memiliki rasa gurih dan manis. Satu porsi Bakmi Gareng dihargai sekitar Rp 18.000,- (arimyname.blogspot.com, 2019). Desa Sudagaran RT 03/03 No.686 Kecamatan Banyumas, Banyumas merupakan informasi yang berupa keterangan tempat penjualan bakmi. Sebelumnya terdapat mis informasi mengenai alamat Bakmi Gareng yang disebutsebut berada di Jl. Perintis Kemerdekaan Purwokerto (tripadvisor.com, 2019). Tungku pemasak dan kipas bamboo merupakan simbol/ lambing dari proses pembuatan bakmi yang masih tradisional.

Penggunaan bahasa pada caption postingan mengenai Bakmi Gareng Banyumas menggunakan bahasa informal. Penggunaan kata "kan" dalam kalimat "enak banget kan kalau kita makan Bakmie", kata "kan" merupakan bentuk tidak baku untuk mengganti kata "bukan" atau "bukankah". Kata "kan" yang merujuk pada kata "bukan" dalam kalimat adalah kata Tanya untuk mengukuhkan isi atau maksud suatu pernyataan, dan diletakkan sesudah pernyataan itu. Penggunaan kata "Bakmie" dalam caption juga tidak sesuai dengan Ejaan Bahasa Indonesia yang Disempurnakan (EYD). Kata "Bakmie" merupakan bentuk tidak baku dari "bakmi". Bakmi menurut Kamus Besar Bahasa Indonesiaa dalah makanan yang bahannya dari tepung (terigu dan sebagainya), bentuknya panjang-panjang seperti tali. Penulisan kata "Bakmie" juga harusnya menggunakan huruf kecil seluruhnya menjadi "bakmi". Bentuk pesannya bersifat persuasif, dapat dilihat dari penggunaan kata "yuk" dalam kalimat "Yuk, yang sedang berwisata di kawasan kota lama Banyumas, bias mampir dan wisata kuliner di Bakmi Gareng". Kata "yuk" menurut KBBI.co.id merupakan pronoun yang mempunyai arti kata seru untuk mengajak; ayo. Jadi, dalam caption tersebut akun @dinporabudpar_banyumas mengajak pengikutnya untuk mampir dan berwisata kuliner ke Bakmi Gareng Banyumas.

Untuk memahami karakteristik konten, maka dapat dilihat dari penggunaan bahasa baik formal maupun informal. Bentuk pesan pada caption terdiri dari pesan yang bersifat informatif dan persuasif. Suatu pesan dirancang dengan upaya untuk menggerakkan khalayak yang disasarnya untuk menentukan pilihan dan keinginannya sendiri. Penggunaan bahasa serta bentuk pesan pada caption menjadi penting karena hal ini merupakan implementasi dari tahap merancang pesan dalam mengembangkan komunikasi pemasaran. Tidak hanya itu, pesan yang efektif sesungguhnya sejalan dengan pemikiran Hermawan (2012) di mana diaharus mencerminkan hal-hal yang bersifat menarik perhatian, mempertahankan ketertarikan membangkitkan keinginan dan menggerakkan tindakan. Hal yang penting dalam pengelolaan akun instagram yang tidak kalah pentingnya adalah memberikan respon terhadap komentar yang diberikan warganet atas unggahan. Berdasarkan pengamatan, maka pengelola akun Instagram 
(a)dinporabudpar banyumas member respon terhadap pesan yang disampaikan melalui akun tersebut, yang sesungguhnya mencerminkan bahwa pesan yang disampaikan telah menarik perhatian khalayak sehingga khalayak menjadi tertarik pada konten dari postingan dengan memberikan komentar. Dalam komentarnya, akun@b_khull menyebutkan akun lain, dalam hal ini bertujuan mengajak orang lain untuk dating ke acara yang diinformasikan. Hal tersebut menandakan bahwa khalayak berkeinginan terhadap produk setelah mendapatkan informasi tentang produk, atau dalam hal ini berkeinginan untuk dating ke acara.

\section{Kesimpulan}

Akun instagam@dinporabudpar_banyumas memiliki peran strategis untuk memperkenalkan potensi unggulan kepariwisataan di Banyumas, yakni wisata alam, wisata budaya dan wisata kuliner Tidak hanya itu, melalui unggahan foto, video serta caption yang informatif dan persuasif, makasemakin terbuka peluang untuk meningkatkan ketertarikan warganet untuk mengunjungi destinasi wista tersebut. Pemanfaatan media sosial ke depan akan semakin menjadi opsi cerdas yang dapat dipilih oleh pemerintah daerah dalam mempromosikan potensi daerah yang dimiliki, sehingga dapat bertransformasi sebagai aset serta sumberdaya yang menggerakkan kemandirian dan kesejahteraan masyarakat di daerah tersebut.

\section{DAFTAR PUSTAKA}

Bungin, B. 2008. Metodologi Penelitian Kualitatif. Jakarta: PT. Raja Grafindo Persada

Eriyanto. 2011. Analisis Isi: Pengantar Metodologi untuk Penelitian Ilmu Komunikasi dan Ilmu-ilmu Sosial Lainnya. Jakarta: Kencana.

Londa, J, W. 2014."Peran Petugas Humas sebagai Komunikator Pembangunan (Studi di Bagian Humas Kantor Pemerintah Kabupaten Minahasa Selatan)". Journal "Acta Diurna", (3), (2).

Marayasa, dkk., 2018. "Penyuluhan Manajemen Menggali Potensi Daerah untuk Meningkatkan Kesejahteraan Perekonomian Masyarakat Kecamatan Leuwi Damar". Jurnal Pengabdian Dharma Laksana. (1), (1). 81-90.

Muflih, R, \& Dany. 2018. "Strategi Government Public Relations Pusat Penerangan TNI dalam Mempertahankan Reputasi Lembaga TNI”. Jurnal Komunikasi Global. (7), (2). 205-216.

Nurjanah, A., \& Nurnisya, F., 2016. "Pemanfaatan Digital Public Relations (PR) dalam Sosialisasi Tagline "jogja istimewa" Humas Pemerintah Kota Yogyakarta. Jurnal Aristo. Vol.4, No. 1. Universitas Muhammadiyah Yogyakarta.

Prihatiningsih, W. 2017. "Motif Penggunaan Media Sosial Instagram di Kalangan Remaja". Jurnal Communication VIII. (1).

Purworini, D. 2014. "Model Informasi Oublik di Era Media Sosial: Kajian Grounded Teori di Pemda Sukoharjo". KomuniTi. (4), (1). Universitas Muhammadiyah Surakarta.

Rachman, R, S. 2018. "Peran Humas Dinas Kebudayaan dan Pariwisata Kota Tangerang dalam Mempromosikan Wisata Situ Cipondoh di Era New Media (Studi Kasus Pengelolaan Website, Instagram dan Tangerang)”. Skripsi, FISIPUniversitas Sultan Ageng Tirtayasa.

Risman, A, dkk. 2015. "Kontribusi Pariwisata Terhadap Peningkatan Kesejahteraan Masyarakat Indonesia". Prosiding KS: Riset \& PKM. (3), (1). 1-154. 
Ruslizar, dkk. 2014. "Fungsi Hubungan Masyarakat pada Dinas Pariwisata dan Ekonomi Kreatif Provinsi Kalimantan Barat dalam Promosi Pariwisata". Jurnal Tesis PMIS UNTAN PSIAN. Universitas Tanjungpura Pontianak.

Sakti \& Yulianto. 2018. "Penggunaan Media Sosial Instagram dalam Pembentukan Identitas Diri Remaja". FISIP Universitas Diponegoro.

Saroddin, S. 2017. "Peranan Humas Pemda dalam Mensosialisasikan Informasi Pembangunan Daerah (Studi di Daerah Kabupaten Jeneponto)". Skripsi. Fakultas Dakwah dan Komunikasi, UIN Alauddin Makassar

Wicaksono, M, A. 2017. "Pengaruh Media Sosial Instagram@wisatadakwahokura Terhadap Minat Berkunjung Followers. ”JOM FISIP. (4), (2). 1-17 